\title{
Rare cases of primary central nervous system anaplastic variant of diffuse large B- cell lymphoma
}

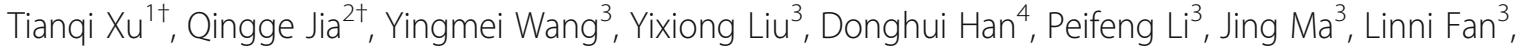 \\ Qingguo $\mathrm{Yan}^{3}$, Shuangping Guo ${ }^{3}$, Mingyang $\mathrm{Li}^{3^{*}}$ and Zhe Wang ${ }^{3^{*}}$
}

\begin{abstract}
Background: Primary central nervous system (CNS) diffuse large B-cell lymphoma (DLBCL) is a rare intracranial tumor, defined as DLBCL arising from the brain, spinal cord, leptomeninges and eye, with an overall annual incidence of 5 cases per million. The primary CNS anaplastic variant of DLBCL (A-DLBCL) is even less common; to our knowledge, there are only two other case reports in the literature. The aim of this report is to present rare cases of primary CNS A-DLBCL and study their clinicopathologic and genetic features.

Case presentation: We report 3 patients, two men and one woman, aged 54, 55 and 67 years old, with primary CNS A-DLBCL. All 3 patients had a high International Extranodal Lymphoma Study Group (IELSG) score; although the patients were treated with methotrexate-based regimens and/or with radiation therapy, the overall survival was only 2, 5, and 8 months. All 3 patients presented with characteristic features of perivascular space infiltration with bizarre-shaped tumor cells, leading to the diagnosis of primary CNS A-DLBCL. Concurrent of MYC and BCL2 and/or $B C L 6$ abnormalities and MYC/BCL2 double-expressor DLBCL occurred in all 3 patients; two patients had MYC/BCL2/ $B C L 6$ triple extra copies, and one patient had MYC extra copy and BCL6 translocation. All 3 patients displayed mutations in MYD88 L265P and nuclear positivity for RELA, RELB and/or c-Rel, indicating constitutive activation of the NF-KB pathway.

Conclusions: These cases shed light on the unique genetic alterations and biological features of primary CNS ADLBCL. Patients with primary CNS A-DLBCL may often have a MYC/BCL2 double-expressor and concurrent MYC and $B C L 2$ and/or BCL6 genetic abnormalities, as well as constitutive activation of the NF-KB pathway. Primary CNS A$\mathrm{DLBCL}$ follows a very aggressive disease course and poor prognosis. In the future, a large number of cases should be analyzed, and the evaluation of molecular genetic characteristics could help with practical and therapeutic implications for primary CNS A-DLBCL.
\end{abstract}

Keywords: Primary central nervous system diffuse large B-cell lymphoma, Anaplastic variant of diffuse large B-cell lymphoma, Concurrent MYC and BCL2 and/or BCL6 abnormalities, MYD88 L265P mutation, Poor prognosis

\section{Background}

Diffuse large B-cell lymphoma (DLBCL) is the most common lymphoma subtype and accounts for $30-40 \%$ of adult non-Hodgkin lymphoma (NHL) [1]. Primary central nervous system (CNS) DLBCL is defined as

\footnotetext{
* Correspondence: leesimn@fmmu.edu.cn; zhwang@fmmu.edu.cn

†Tianqi Xu and Qingge Jia contributed equally to this work.

${ }^{3}$ State Key Laboratory of Cancer Biology, Department of Pathology, Xijing Hospital and School of Basic Medicine, Fourth Military Medical University, Xi'an 710032, China

Full list of author information is available at the end of the article
}

DLBCL arising from the brain, spinal cord, leptomeninges and eye. Primary CNS DLBCL is a rare subtype of B-cell lymphoma, which represents less than $1 \%$ of all NHL and 2.4-3\% of all brain tumors [2], and is classified as a distinct entity in the WHO classification of tumors in hematopoietic and lymphoid tissues [1]. Statistics shows a peak incidence of patients aged 50 to 60 years (median 56 years old); however, in the recent two decades, there is an increasing incidence of reported patients over the age of 60 years old with primary CNS

(C) The Author(s). 2019 Open Access This article is distributed under the terms of the Creative Commons Attribution 4.0 International License (http://creativecommons.org/licenses/by/4.0/), which permits unrestricted use, distribution, and 
DLBCL [3]. As it is difficult to make an early diagnosis and because targeted therapy is lacking, primary CNS DLBCL usually shows poorer prognosis than extraneural systemic DLBCL [3].

DLBCL, not otherwise specified (DLBCL, NOS) is morphologically diverse and is generally divided into 3 morphological variants: centroblastic, immunoblastic, and anaplastic [1]. The anaplastic variant of DLBCL (A-DLBCL) is an uncommon morphologic variant that represents approximately $3.4 \%$ of all DLBCL cases $[4,5]$ and is characterized by large to very large polygonal cells with bizarre pleomorphic nuclei that resemble tumor cells of anaplastic large cell lymphoma (ALCL) [1]. Recently, we reported that A-DLBCL had a high frequency of TP53 mutations and concurrent MYC and BCL2 and/ or $B C L 6$ genetic abnormalities, indicating that the clinicopathologic features and aggressive behavior of A-DLBCL are distinct from the common DLBCL [6].

Because of the rarity, to our knowledge, there are only two case reports describing primary CNS A-DLBCL in the literature $[7,8]$. In this study, we reported on 3 patients with primary CNS A-DLBCL and studied their clinicopathologic and genetic features to provide further information for diagnostic and prognostic assessments as well as treatments of this distinctive type of DLBCL.

\section{Case presentation Clinical findings \\ Case 1}

A 67-year-old man was admitted to our hospital with intermittent headache for 10 days and hypomnesis for a week. The patient had no B symptoms but was generally in poor condition (Eastern Cooperative Oncology Group (ECOG) performance status $=2$ ). Neuroimaging revealed a homogeneously enhancing mass with peripheral signal hyperintensity on the right temporal. Serum lactate dehydrogenase $(\mathrm{LDH})$ level $(630 \mathrm{U} / \mathrm{L}$, reference range: 135-215 U/L) and cerebrospinal fluid (CSF) protein concentration $(954 \mathrm{mg} / \mathrm{L}$, reference range: $150-450 \mathrm{mg} / \mathrm{L}$ ) were elevated in the patient. Involvement of deep structures of the brain was not found. The International Extranodal Lymphoma Study Group (IELSG) score [9] was 4 and belonged to the high-risk group. This patient received high-dose methotrexate (HD-MTX) $\left(3.5 \mathrm{~g} / \mathrm{m}^{2}\right)$ and the concomitant chemotherapy drug idarubicin after surgery. The patient achieved a partial remission according to the response criteria [10] after therapy but died 5 months after the onset of disease.

\section{Case 2}

A 54-year-old man was admitted to our hospital with a history of right limb weakness for 1 year. The patient had no B symptoms, and the general condition was good $($ ECOG performance status $=0$ ). Neuroimaging showed a noncalcified homogeneously enhancing mass with peripheral signal hyperintensity around the ventricles with associated edema and multiple damaged parts. Serum LDH level (375 U/L) and CSF protein concentration $(625 \mathrm{mg} / \mathrm{L})$ were elevated. Involvement of deep structures of the brain was found, and the IELSG score was 4 and belonged to the high-risk group. This patient received HD-MTX $\left(3.5 \mathrm{~g} / \mathrm{m}^{2}\right)$ and the concomitant chemotherapy drug cytarabine after surgery followed by consolidative whole-brain radiotherapy (40 Gy). He achieved a PR after therapy but died 8 months after diagnosis.

\section{Case 3}

A 55-year-old woman was admitted to our hospital with history of dizzy and headache for 1 year. The patient had no B symptoms and her general condition was poor (ECOG performance status $=3$ ). Neuroimaging revealed a homogeneously enhancing mass with peripheral signal hyperintensity on the interventricular septum and the corpus callosum with associated obstructive hydrocephalus. Serum LDH level (780 U/L) and CSF protein concentration $(863 \mathrm{mg} / \mathrm{L})$ were elevated. Involvement of deep structures of the brain was found, and the IELSG score was 4 and belonged to the high-risk group. This patient received HD-MTX $\left(3.5 \mathrm{~g} / \mathrm{m}^{2}\right)$ and the concomitant chemotherapy drug idarubicin after surgery. She had progressive disease after therapy and died within 2 months of diagnosis.

\section{Pathological findings}

All 3 patients showed diffuse infiltration in a sheet-like pattern and replacement of the brain parenchyma by large atypical lymphoid cells. At the edge of the tumor or in areas with a low density of tumor cells, characteristic features, including tumor cell infiltration in perivascular spaces, were observed. Polymorphic large polygonal tumor cells with anaplastic features were observed and scattered in the background of ordinary DLBCLs in all 3 patients, as described by Li et al. [6]. These cells were characterized by single or multiple irregular giant nuclei with hyperchromatin, thick nuclear membranes, and large nucleoli, which were similar to Reed-Sternberg-like cells (Fig. 1a-f).

The immunohistochemistry results are listed in Table 1 . All 3 patients were strongly positive for CD20 and negative for CD3, ALK and EBER. According to Hans [11] and Choi algorithms [12], patients 2 and 3 demonstrated a non-GCB immunophenotype, whereas patient 1 demonstrated a GCB immunophenotype. The $\mathrm{Ki}-67$ proliferation rate was generally high, ranging from 70 to $90 \%$. The CD30 expression was positive in patient 1 but negative in patients 2 and 3. All 3 patients tested positive for both BCL2 (Fig. 1g) and MYC (Fig. 1h) 

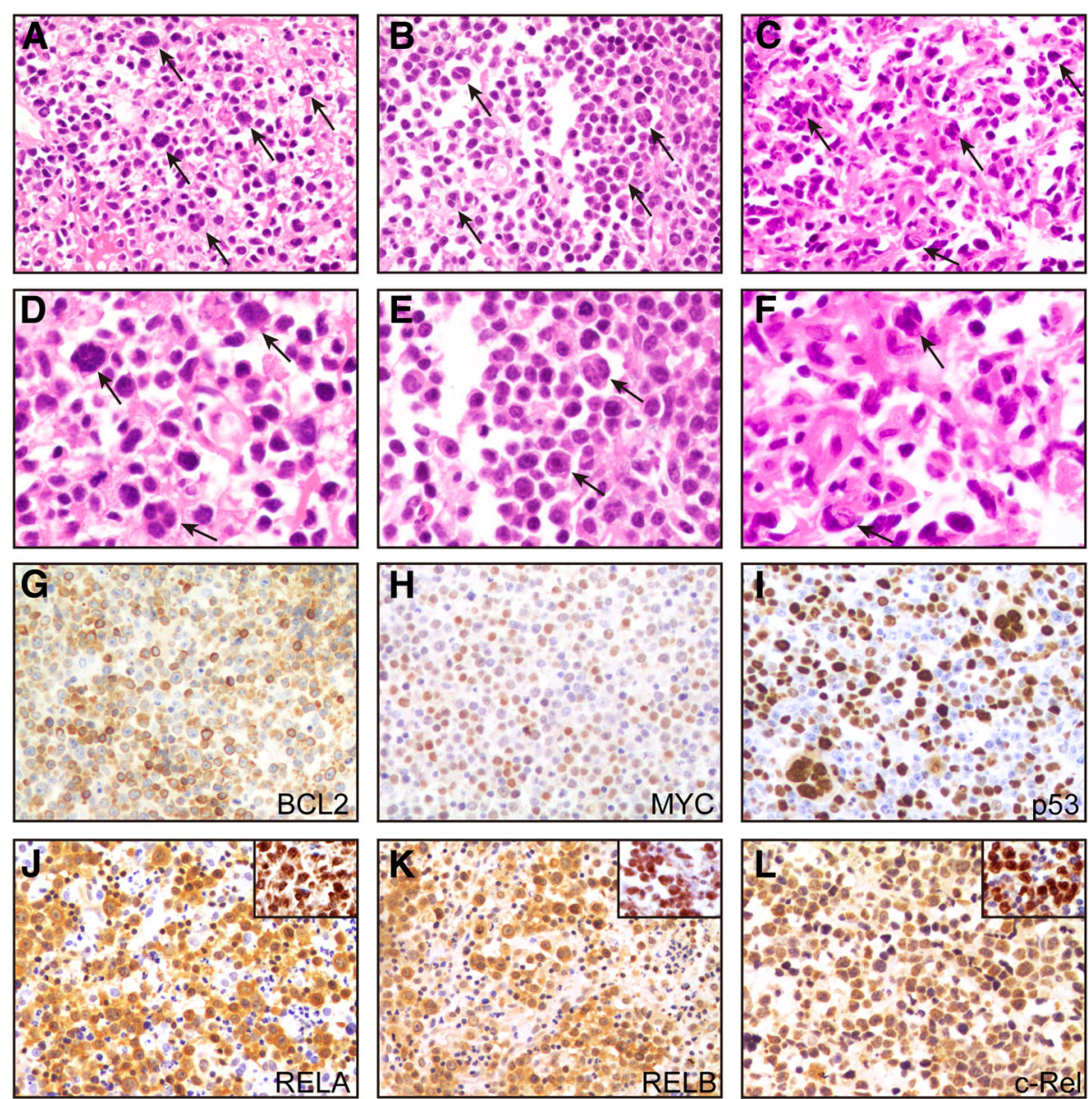

Fig. 1 Representative hematoxylin and eosin (H\&E) and immunostaining analysis of primary CNS A-DLBCL. (a-c) All three cases showed scattered binucleated and multinucleated, bizarre Reed-Sternberg-like tumor cells (black arrow) in the background of ordinary DLBCL (a: patient 1, b: patient 2, c: patient 3). (d-f) A high power view of the anaplastic tumor cells of each case (d: patient 1, e: patient 2, f: patient 3). Tumor cells of patient 3 showed a diffuse strong positivity for BCL2 (g), MYC (h) and p53 (i). Patient 2 showed positive staining for the NF-KB subunits RELA (j), RELB (k) and c-Rel (I) in both cytoplasm and nucleus. A positive control of each immunostaining for anaplastic DLBCL tissues inset at the upper right corner

(double-expressor). With respect to p53 staining, patient 1 had completely negative staining, patient 2 had variable expression $(>50 \%)$, and patient 3 had diffusely positive staining (Fig. 1i). Of the three NF- $k B$ subunits including RELA, RELB and c-Rel, all 3 patients expressed at least two subunits of NF- $\mathrm{kB}$ in both cytoplasm and nucleus (patient 3 was negative for c-Rel) (Fig. 1j-1), indicating the nuclear translocation and activation of the NF-kB pathway.

The results of FISH and mutation status are listed in Table 1. Patients 1 and 2 had extra copies for all $M Y C$, $B C L 2$ and BCL6 genes (Fig. 2a-c), Patient 3 had an extra copy of $M Y C$ and a translocation of BCL6. With respect to mutation status, all 3 patients were successfully amplified for TP53 exons 5-10, MYD88 exon 5, CD79B exon 5, CARD11 exons 5-9 and EZH2 exon 16. MYD88 L265P mutations were detected in all 3 patients, and patient 3 displayed the TP53 R273C mutation (Fig. 2d-f).
No mutations were identified for $C D 79 B, C A R D 11$ and $E Z H 2$ in these patients.

\section{Discussion}

Primary CNS DLBCL is a rare entity with poor prognosis and needs a better understanding of the genetic characteristics and prognostic markers [13]. In terms of morphology, primary CNS A-DLBCL is an extremely uncommon lymphoma that has been described in only two other case reports to date but without intact clinicopathologic characteristics $[7,8]$. In the 3 cases of this study, the characteristic features of perivascular space infiltration with bizarre-shaped tumor cells led to the diagnosis of primary CNS A-DLBCL after excluding systemic DLBCL with CNS involvement. It is important to realize the existence of primary CNS A-DLBCL to avoid being misdiagnosed as ALCL or undifferentiated carcinoma. The former is positive for CD30 and/or ALK and 


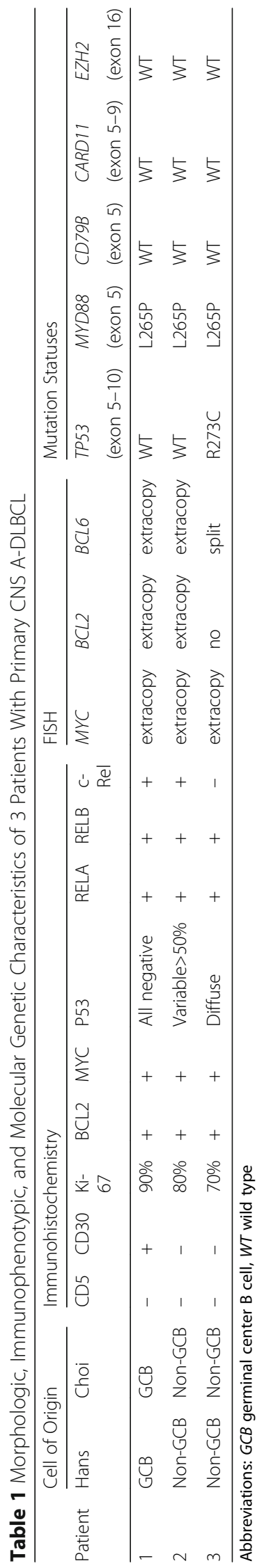




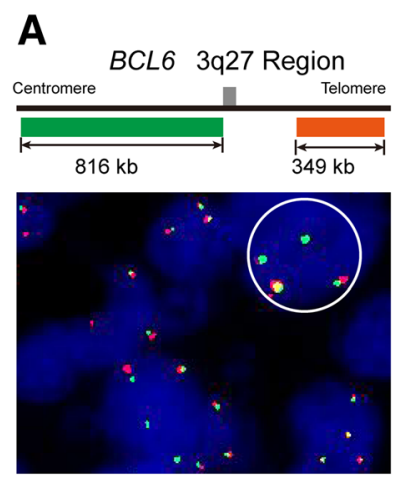

D

MYD88 c.794T>C p.L265P

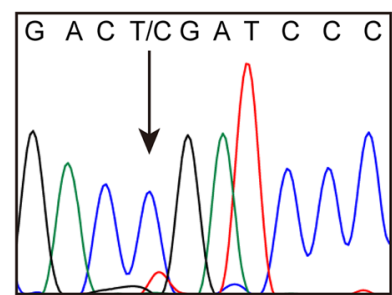

B

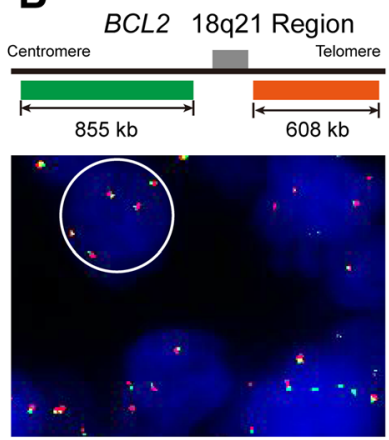

E

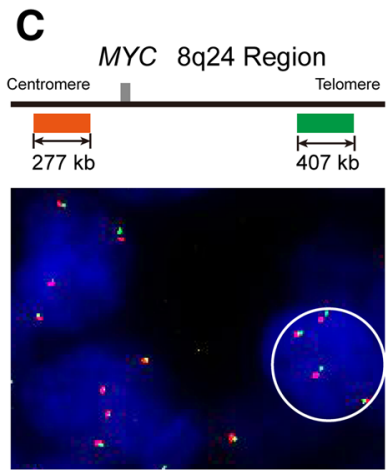

$\mathbf{F}$ c.794T>C p.L265P
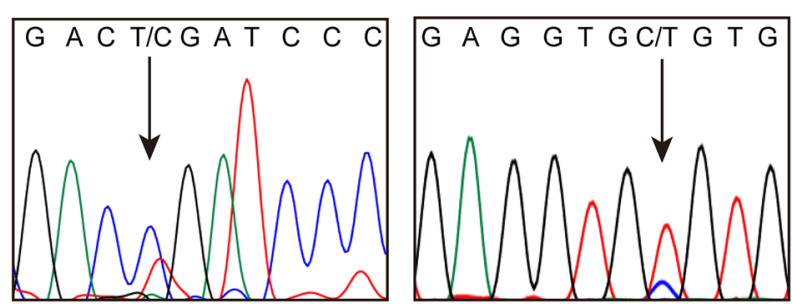

Fig. 2 Representative results of fluorescence in situ hybridization (FISH) analysis and Sanger sequencing of primary CNS A-DLBCL. The FISH analysis for patient 1 showed extra copy signals for BCL6 (a), BCL2 (b) and MYC (c). MYD88 L265P mutations in patients 1 (d) and 2 (e), in which a CTG (leucine) codon was changed to a CCG (proline) codon. TP53 R273C mutation of patient 3 (f), in which a CGT (arginine) codon was changed to a TGT (cysteine) codon

negative for B-cell markers, whereas primary CNS A-DLBCL expresses B-cell markers with negativity for ALK. Negativity for cytokeratin is helpful in distinguishing this type of DLBCL from undifferentiated carcinoma [14].

In our previous study of 35 patients with A-DLBCL, we defined A-DLBCL based on morphology and recognized the distinctiveness of this neoplasm from ordinary DLBCLs in terms of genetic alterations and biologic features, which contained a high incidence of p53 positivity and MYC/BCL2 double-expressor and a high frequency of TP53 mutations and concurrent MYC and BCL2 and/ or BCL6 abnormalities [6]. In the 3 patients with primary CNS A-DLBCL in this study, the concurrent of $M Y C$ and BCL2 and/or BCL6 abnormalities and MYC/ BCL2 double-expressor occurred in all 3 patients, in which two patients had $M Y C / B C L 2 / B C L 6$ triple extra copies, and one patient had MYC extra copy and BCL6 translocation. The pattern of genetic abnormalities of these genes was overwhelmingly having an extra copy except $B C L 6$ translocation in case 3 , which is consistent with translocations recurrently affecting BCL6 and IG genes, whereas $M Y C$ translocations are rare and $B C L 2$ translocations are absent in primary CNS DLBCL [1517]. The prognostic value of gain/amplification of $M Y C$ is still unclear in DLBCL, and some studies reported that gain/amplification of $M Y C$ is not associated with a poor prognosis [18-20]. Moreover, BCL2 gain/amplification is associated with cell-of-origin-specific (activated B-cell-like subtype) clinical effect in R-CHOP-treated DLBCL [21]. In our previous study about A-DLBCL [6], $M Y C / B C L 2 / B C L 6$ triple extra copies were found in 3 cases, and the overall survival is 5,9 , and 11 months, similar to the very aggressive disease course and poor prognosis of primary CNS A-DLBCL cases in this study, suggesting that in this specific morphology (anaplastic variant), $M Y C / B C L 2 / B C L 6$ copy number alterations may be an adverse prognostic factor, but more cases are needed to confirm this finding.

We detected one patient with diffuse positive p53 immunostaining and TP53 gene mutation (R273C). The TP53 mutation rate is approximately $20 \%$ in DLBCL [22] and approximately $26.7-37.2 \%$ [23, 24] in primary CNS DLBCL. However, few studies that report TP53 mutation status in PCNSL reveal incidences $<10 \%[25$, 26]. Moreover, we also found one patient had a TP53 null phenotype (completely negative), similar to that seen in high grade serous carcinomas [27]. Tumors that were completely negative for p53 IHC expression had a mutation of TP53 in 65\% of cases and wild-type TP53 in $11 \%$. Therefore, complete absence of p53 immunostaining is commonly associated with a TP53 mutation status. 
However, the TP53 exon 5-10 of this patient was wild type by sanger sequencing, suggesting that there may be a wild-type TP53 or variations in other positions besides exon 5-10. TP53 mutations alter the wild-type p53 protein structure and disrupt its function, which is implicated in lymphomagenesis and disease progression [28]. The genomic instability driven by the TP53 mutation and $M Y C, B C L 2$, and $B C L 6$ abnormalities might partially explain the poor clinical course and may be good prognostic factors in patients with primary CNS A-DLBCL. It seems that these genetic alterations probably occurred more frequently in primary CNS A-DLBCL patients than in patients with ordinary primary CNS DLBCL without anaplastic features, suggesting that the morphology is closely related to genetic alterations and disease prognosis. However, as there are rare reports of primary CNS A-DLBCL, it is necessary to confirm our observations with a large number of cases in the future.

In primary CNS DLBCL, mutations of MYD88 are believed to promote lymphomagenesis via constitutive activation of the NF- $\mathrm{kB}$ pathway. MYD88 is an adaptor molecule in the Toll-like receptor pathway that mediates interleukin-1 receptor signaling [29]. A somatic mutation of MYD88 is found in 67-86\% [26] [30,31] of primary CNS DLBCL, and the most common mutation site is L265P. In this study, all 3 primary CNS A-DLBCL patients displayed mutations in MYD88 L265P, which is consistent with the high frequency of MYD88 alterations reported in the literature for primary CNS DLBCL. The high frequency of MYD88 mutations in primary CNS A-DLBCL are probably not unique to the anaplastic variant, but mainly due to the site of CNS. Because the frequency of MYD88 mutation appeared to be higher in this small series than that of A-DLBCL in our previous study $(100 \%$ vs $20 \%)$ [6]. The activation of the NF- $\mathrm{KB}$ pathway leads to the nuclear translocation of NF- $\mathrm{kB}$ dimers and subsequently initiates activation of other target genes [32]. In all 3 cases in this study, tumor cells expressed at least 2 nuclear NF- $\mathrm{kB}$ subunits, suggesting that NF- $\kappa B$ signaling activation is an almost universal feature of primary CNS A-DLBCL. Given the high prevalence of MYD 88 mutations in primary CNS A-DLBCL, treatment with ibrutinib, which inhibits Bruton's Tyrosine Kinase (BTK) and further suppresses NF- $\mathrm{kB}$ and STAT3 activation and tumor growth, or treatment with bortezomib, which is effective for $C D 79 B / M Y D 88^{\mathrm{L} 265 \mathrm{P}}$ double-mutant DLBCLs [33], could be considered in patients with primary CNS A-DLBCL [34].

Current treatment for primary CNS DLBCL includes surgery followed by chemotherapy with methotrexatebased regimens, with or without adjuvant radiation therapy [3, 13]. Unlike other brain tumors, primary CNS DLBCL regularly has a good response to chemotherapy and radiation therapy, but in comparison with lymphomas outside the CNS, survival is not as prominent, partly due to inadequate penetration of the blood-brain barrier [35]. Most protocols report a median progression-free survival of approximately 12 months and an overall survival (OS) of approximately 3 years. However, the prognosis for primary CNS DLBCL that has failed first-line therapy remains poor, with a low median OS of 12 months [13]. In the 3 patients with primary CNS A-DLBCL in this study, the median OS was only 5 months, which is much lower than that of primary CNS DLBCL and A-DLBCL (16 months) [6]. The International Prognostic Index (IPI) score used for determining the prognosis of patients with aggressive NHL seems not fit into primary CNS DLBCL. The IELSG score, including five parameters (age, ECOG performance status, LDH level, CSF protein concentration, deep brain involvement), is widely used to predict outcomes and to better stratify patients. The presence of 0 to 1,2 to 3 , or 4 to 5 adverse risk factors correlates with 2 -year survival rates of $80,48 \%$, or $15 \%$, respectively [9]. In our 3 cases, the scores of patients were all 4, suggesting an aggressive disease course and poor survival, in accordance with intricate genetic alterations and adverse prognosis factors.

\section{Conclusions}

In summary, patients with primary CNS A-DLBCL may often have a MYC/BCL2 double-expressor and concurrent $M Y C$ and $B C L 2$ and/or BCL6 genetic abnormalities, as well as constitutive activation of the NF- $\mathrm{kB}$ pathway. The importance of this type of lymphoma is likely underestimated, and recognition is likely important because most patients follow a very aggressive disease course and have a poor prognosis. In the future, a large number of cases should be analyzed, and an evaluation of molecular genetic alterations could help with practical and therapeutic implications for primary CNS A-DLBCL.

\section{Abbreviations \\ A-DLBCL: Anaplastic variant of DLBCL; ALCL: Anaplastic large cell lymphoma; BTK: Bruton's Tyrosine Kinase; CNS: Central nervous system; CSF: Cerebrospinal fluid; DHL: Double-hit lymphoma; DLBCL: Diffuse large B- cell lymphoma; ECOG: Eastern Cooperative Oncology Group; HD-MTX: High- dose methotrexate; IELSG: International Extranodal Lymphoma Study Group; IPI: International Prognostic Index; LDH: Lactate dehydrogenase; NHL: Non- Hodgkin lymphoma; OS: Overall survival; PD: Progressive disease; PR: Partial remission; THL: Triple-hit lymphoma; WBRT: Whole-brain radiotherapy}

\section{Acknowledgements}

Not applicable.

Funding

This work was supported by grants from the National Natural Science Foundation of China (No. 81472402, 81570176 and 81570180).

Availability of data and materials

The surgical materials and the datasets analyzed during the current study are available from the corresponding author on reasonable request. 


\section{Authors' contributions}

TX and QJ: reviewing the cases and writing of manuscript. YW and YL: FISH and IHC analyses. DH, PL and JM: collection of clinical data. LF, QY and SG: pathological diagnosis. ML and ZW: revision of manuscript. All authors read and approved the final manuscript prior to submission.

\section{Ethics approval and consent to participate}

Not applicable.

\section{Consent for publication}

Written informed consent for publication of their clinical details and clinical images was obtained from the patients. A copy of the consent form is available for review by the Editor of this journal.

\section{Competing interests}

The authors declare no conflicts of interest.

\section{Publisher's Note}

Springer Nature remains neutral with regard to jurisdictional claims in published maps and institutional affiliations.

\section{Author details}

'Department of Hematology, Xijing Hospital, Fourth Military Medical University, Xi'an 710032, China. ${ }^{2}$ Second Retired Cadres Sanitarium of Xi'an, Shaanxi Province Military Region, Xi'an 710032, China. ${ }^{3}$ State Key Laboratory of Cancer Biology, Department of Pathology, Xijing Hospital and School of Basic Medicine, Fourth Military Medical University, Xi'an 710032, China. ${ }^{4}$ Department of Urology, Xijing Hospital, Fourth Military Medical University, Xi'an 710032, China.

\section{Received: 24 January 2019 Accepted: 13 May 2019}

Published online: 20 May 2019

\section{References}

1. Swerdlow SH, Campo E, Pileri SA, Harris NL, Stein H, Siebert R, Advani R, Ghielmini M, Salles GA, Zelenetz AD, Jaffe ES. The 2016 revision of the World Health Organization classification of lymphoid neoplasms. Blood. 2016;127:2375-90

2. Schlegel U. Primary CNS Iymphoma. Ther Adv Neurol Disord. 2009:2:93-104.

3. Grommes C, LM DA. Primary CNS Lymphoma. Journal of clinical oncology : official journal of the American Society of Clinical Oncology. 2017;35:2410-8.

4. Diebold J, Anderson JR, Armitage JO, Connors JM, Maclennan KA, MullerHermelink HK, Nathwani BN, Ullrich F, Weisenburger DD. Diffuse large B-cell lymphoma: a clinicopathologic analysis of 444 cases classified according to the updated Kiel classification. Leukemia \& lymphoma. 2002;43:97-104.

5. Weisenburger DD, Anderson JR, Diebold J, Gascoyne RD, MacLennan KA, Muller-Hermelink HK, Nathwani BN, Ullrich F, Armitage JO. Systemic anaplastic large-cell lymphoma: results from the non-Hodgkin's lymphoma classification project. Am J Hematol. 2001;67:172-8.

6. Li M, Liu Y, Wang Y, Chen G, Chen Q, Xiao H, Liu F, Qi C, Yu Z, Li X, Fan L, Guo Y, Yan Q, Guo S, Wang Z. Anaplastic variant of diffuse large B-cell Lymphoma displays intricate genetic alterations and distinct biological features. Am J Surg Pathol. 2017:41:1322-32.

7. Yang T, Belverud S, Yeh AY, Bandovic J, Farmer P, Woldenberg RF, Demopoulos A, Schulder M, Li JY. Primary CNS anaplastic diffuse large B-cell lymphoma mimicking undifferentiated metastatic tumors: a case report. J Neuro-Oncol. 2010;96:433-6.

8. Shimura T, Sugisaki Y, Fukino K, Node Y, Teramoto A, Kawamoto M. Detection of Epstein-Barr virus DNA and expression of CD30 antigen in primary anaplastic diffuse large B-cell lymphoma of the brain. Brain tumor pathology. 2001:18:161-5.

9. Ferreri AJ, Blay JY, Reni M, Pasini F, Spina M, Ambrosetti A, Calderoni A, Rossi A, Vavassori V, Conconi A, Devizzi L, Berger F, Ponzoni M, Borisch B, Tinguely M, Cerati M, Milani M, Orvieto E, Sanchez J, Chevreau C, Dell'Oro S, Zucca E, Cavalli F. Prognostic scoring system for primary CNS lymphomas: the international Extranodal Lymphoma study group experience. Journal of clinical oncology : official journal of the American Society of Clinical Oncology. 2003:21:266-72.

10. Abrey LE, Batchelor TT, Ferreri AJ, Gospodarowicz M, Pulczynski EJ, Zucca E, Smith JR, Korfel A, Soussain C, DeAngelis LM, Neuwelt EA, O'Neill BP, Thiel E, Shenkier T, Graus F, van den Bent M, Seymour JF, Poortmans P, Armitage
JO, Cavalli F. International Primary CNSLCG. Report of an international workshop to standardize baseline evaluation and response criteria for primary CNS Iymphoma. Journal of clinical oncology : official journal of the American Society of Clinical Oncology. 2005:23:5034-43.

11. Hans CP, Weisenburger DD, Greiner TC, Gascoyne RD, Delabie J, Ott G, MullerHermelink HK, Campo E, Braziel RM, Jaffe ES, Pan Z, Farinha P, Smith LM, Falini B, Banham AH, Rosenwald A, Staudt LM, Connors JM, Armitage JO, Chan WC. Confirmation of the molecular classification of diffuse large B-cell lymphoma by immunohistochemistry using a tissue microarray. Blood. 2004;103:275-82.

12. Choi WW, Weisenburger DD, Greiner TC, Piris MA, Banham AH, Delabie J, Braziel RM, Geng H, labal J, Lenz G, Vose JM, Hans CP, Fu K, Smith LM, Li M, Liu Z, Gascoyne RD, Rosenwald A, Ott G, Rimsza LM, Campo E, Jaffe ES, Jaye DL, Staudt LM, Chan WC. A new immunostain algorithm classifies diffuse large B-cell lymphoma into molecular subtypes with high accuracy. Clinical cancer research : an official journal of the American Association for Cancer Research. 2009;15:5494-502.

13. Han $\mathrm{CH}$, Batchelor $\Pi$. Diagnosis and management of primary central nervous system lymphoma. Cancer. 2017;123:4314-24.

14. Guo S, Bai Q, Rohr J, Wang Y, Liu Y, Zeng K, Yu K, Zhang X, Wang Z. Clinicopathological features of primary diffuse large B-cell lymphoma of the central nervous system - strong EZH2 expression implying diagnostic and therapeutic implication. APMIS : acta pathologica. microbiologica, et immunologica Scandinavica. 2016;124:1054-62.

15. Brune V, Tiacci E, Pfeil I, Doring C, Eckerle S, van Noesel CJ, Klapper W, Falini B, von Heydebreck A, Metzler D, Brauninger A, Hansmann ML, Kuppers R. Origin and pathogenesis of nodular lymphocyte-predominant Hodgkin lymphoma as revealed by global gene expression analysis. J Exp Med. 2008;205:2251-68.

16. Cady FM, O'Neill BP, Law ME, Decker PA, Kurtz DM, Giannini C, Porter AB, Kurtin PJ, Johnston PB, Dogan A, Remstein ED. Del(6)(q22) and BCL6 rearrangements in primary CNS lymphoma are indicators of an aggressive clinical course. Journal of clinical oncology : official journal of the American Society of Clinical Oncology. 2008:26:4814-9.

17. Montesinos-Rongen M, Zuhlke-Jenisch R, Gesk S, Martin-Subero Jl, Schaller C, Van Roost D, Wiestler OD, Deckert M, Siebert R. Interphase cytogenetic analysis of lymphoma-associated chromosomal breakpoints in primary diffuse large B-cell lymphomas of the central nervous system. J Neuropathol Exp Neurol. 2002;61:926-33.

18. Landsburg DJ, Falkiewicz MK, Petrich AM, Chu BA, Behdad A, Li S, Medeiros LJ, Cassaday RD, Reddy NM, Bast MA, Vose JM, Kruczek KR, Smith SE, Patel P, Hernandez-llizaliturri F, Karmali R, Rajguru S, Yang DT, Maly JJ, Blum KA, Zhao W, Vanslambrouck C, Nabhan C. Sole rearrangement but not amplification of MYC is associated with a poor prognosis in patients with diffuse large B cell lymphoma and B cell lymphoma unclassifiable. Br J Haematol. 2016;175:631-40.

19. Valera A, Lopez-Guillermo A, Cardesa-Salzmann T, Climent F, Gonzalez-Barca E, Mercadal S, Espinosa I, Novelli S, Briones J, Mate JL, Salamero O, Sancho JM, Arenillas L, Serrano S, Erill N, Martinez D, Castillo P, Rovira J, Martinez A, Campo E, Colomo L. Grup per l'Estudi dels Limfomes de Catalunya i B. MYC protein expression and genetic alterations have prognostic impact in patients with diffuse large B-cell lymphoma treated with immunochemotherapy. Haematologica. 2013;98:1554-62.

20. Testoni M, Kwee I, Greiner TC, Montes-Moreno S, Vose J, Chan WC, Chiappella A, Baldini L, Ferreri AJ, Gaidano G, Mian M, Zucca E, Bertoni F. Gains of MYC locus and outcome in patients with diffuse large B-cell lymphoma treated with R-CHOP. Br J Haematol. 2011;155:274-7.

21. Ennishi D, Mottok A, Ben-Neriah S, Shulha HP, Farinha P, Chan FC, Meissner B, Boyle M, Hother C, Kridel R, Lai D, Saberi S, Bashashati A, Shah SP, Morin RD, Marra MA, Savage KJ, Sehn LH, Steidl C, Connors JM, Gascoyne RD, Scott DW. Genetic profiling of MYC and BCL2 in diffuse large B-cell lymphoma determines cell-of-origin-specific clinical impact. Blood. 2017:129:2760-70.

22. Xu-Monette ZY, Wu L, Visco C, Tai YC, Tzankov A, Liu WM, Montes-Moreno S, Dybkaer K, Chiu A, Orazi A, Zu Y, Bhagat G, Richards KL, Hsi ED, Zhao XF, Choi WW, Zhao X, van Krieken JH, Huang Q, Huh J, Ai W, Ponzoni M, Ferreri AJ, Zhou F, Kahl BS, Winter JN, Xu W, Li J, Go RS, Li Y, Piris MA, Moller MB, Miranda RN, Abruzzo LV, Medeiros LJ, Young KH. Mutational profile and prognostic significance of TP53 in diffuse large B-cell lymphoma patients treated with R-CHOP: report from an international DLBCL rituximab-CHOP consortium program study. Blood. 2012;120:3986-96.

23. Zorofchian S, El-Achi H, Yan Y, Esquenazi Y, Ballester LY. Characterization of genomic alterations in primary central nervous system lymphomas. J NeuroOncol. 2018;140:509-17. 
24. Munch-Petersen HD, Asmar F, Dimopoulos K, Areskeviciute A, Brown P, Girkov MS, Pedersen A, Sjo LD, Heegaard S, Broholm H, Kristensen LS,

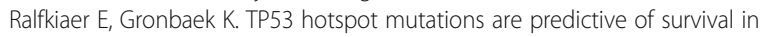
primary central nervous system lymphoma patients treated with combination chemotherapy. Acta neuropathologica communications. 2016; 4.40

25. Cobbers JM, Wolter M, Reifenberger J, Ring GU, Jessen F, An HX, Niederacher D, Schmidt EE, Ichimura K, Floeth F, Kirsch L, Borchard F, Louis $D N$, Collins VP, Reifenberger G. Frequent inactivation of CDKN2A and rare mutation of TP53 in PCNSL. Brain Pathol. 1998;8:263-76.

26. Nakamura T, Tateishi K, Niwa T, Matsushita Y, Tamura K, Kinoshita M, Tanaka K, Fukushima S, Takami H, Arita H, Kubo A, Shuto T, Ohno M, Miyakita Y, Kocialkowski S, Sasayama T, Hashimoto N, Maehara T, Shibui S, Ushijima T, Kawahara N, Narita Y, Ichimura K. Recurrent mutations of CD79B and MYD88 are the hallmark of primary central nervous system lymphomas. Neuropathol Appl Neurobiol. 2016;42:279-90.

27. Yemelyanova A, Vang R, Kshirsagar M, Lu D, Marks MA, Shih le M, Kurman RJ. Immunohistochemical staining patterns of p53 can serve as a surrogate marker for TP53 mutations in ovarian carcinoma: an immunohistochemical and nucleotide sequencing analysis. Modern pathology : an official journal of the United States and Canadian academy of pathology. Inc. 2011;24: 1248-53.

28. Levine AJ, Vosburgh E. P53 mutations in lymphomas: position matters. Blood. 2008;112:2997-8.

29. Fitzgerald KA, Palsson-McDermott EM, Bowie AG, Jefferies CA, Mansell AS, Brady G, Brint E, Dunne A, Gray P, Harte MT, McMurray D, Smith DE, Sims JE, Bird TA, O'Neill LA. Mal (MyD88-adapter-like) is required for toll-like receptor-4 signal transduction. Nature. 2001;413:78-83.

30. Nayyar N, White MD, Gill CM, Lastrapes M, Bertalan M, Kaplan A, D'Andrea MR, Bihun I, Kaneb A, Dietrich J, Ferry JA, Martinez-Lage M, Giobbie-Hurder A, Borger DR, Rodriguez FJ, Frosch MP, Batchelor E, Hoang K, Kuter B, Fortin S, Holdhoff M, Cahill DP, Carter S, Brastianos PK, Batchelor TT. MYD88 L265P mutation and CDKN2A loss are early mutational events in primary central nervous system diffuse large B-cell lymphomas. Blood advances. 2019;3: 375-83

31. Chapuy B, Roemer MG, Stewart C, Tan Y, Abo RP, Zhang L, Dunford AJ, Meredith DM, Thorner AR, Jordanova ES, Liu G, Feuerhake F, Ducar MD, Illerhaus G, Gusenleitner D, Linden EA, Sun HH, Homer H, Aono M, Pinkus GS, Ligon AH, Ligon KL, Ferry JA, Freeman GJ, van Hummelen P, Golub TR, Getz G, Rodig SJ, de Jong D, Monti S, Shipp MA. Targetable genetic features of primary testicular and primary central nervous system lymphomas. Blood. 2016;127:869-81.

32. Lim KH, Yang Y, Staudt LM. Pathogenetic importance and therapeutic implications of NF-kappaB in lymphoid malignancies. Immunol Rev. 2012; 246:359-78

33. Cummin TE, Du MQ, Johnson P. Genetics of diffuse large B-cell Lymphoma. N Engl J Med. 2018;379:493.

34. Wilson WH, Young RM, Schmitz R, Yang Y, Pittaluga S, Wright G, Lih CJ, Williams PM, Shaffer AL, Gerecitano J, de Vos S, Goy A, Kenkre VP, Barr PM, Blum KA, Shustov A, Advani R, Fowler NH, Vose JM, Elstrom RL, Habermann TM, Barrientos JC, McGreivy J, Fardis M, Chang BY, Clow F, Munneke B, Moussa D, Beaupre DM, Staudt LM. Targeting B cell receptor signaling with ibrutinib in diffuse large B cell lymphoma. Nat Med. 2015;21:922-6.

35. Korfel A, Schlegel U. Diagnosis and treatment of primary CNS lymphoma. Nat Rev Neurol. 2013:9:317-27.

Ready to submit your research? Choose BMC and benefit from:

- fast, convenient online submission

- thorough peer review by experienced researchers in your field

- rapid publication on acceptance

- support for research data, including large and complex data types

- gold Open Access which fosters wider collaboration and increased citations

- maximum visibility for your research: over $100 \mathrm{M}$ website views per year

At BMC, research is always in progress.

Learn more biomedcentral.com/submissions 